\title{
Comparative Assessment of Supervisory Regulations Related to Appointment, Training and Change of Location
}

\author{
Gulsun Atanur Baskan¹, *Saduman Kapusuzoglu² \\ ${ }^{1}$ Hacettepe University, Ankara, Turkey \\ ${ }^{2}$ Abant Izzet Baysal University, Bolu, Turkey \\ *sadumankapusuzoglu@gmail.com
}

\begin{abstract}
The purpose of this study is to compare and assess the Regulations of Elementary Education Directorates and Education Supervisors Directorates approved in 2011 from structure, process and rationale. In accordance with this purpose, the opinions of education supervisors $(\mathrm{N}=74)$ were determined by the questionnaire developed in accordance with the regulations by the researchers and consisted of 35 items. Data gathered was analyzed by mean. As a result, it was reached to the conclusion that supervisors do not agree with the changes related to application requirements to competitive exam. They agreed with the changes related to the items such as organization of written exam, appointment and location changes, extension of scope of duty of supervisors "partially" and they agreed with the changes related to subjects and point weights of competitive exam training and appointments of supervisors.
\end{abstract}

Keywords: Regulations; supervision; comparative assessment

\section{Introduction}

In this section, the changes occurred in the matters such as articles concerning the research, the constitution and other laws which are the legal foundations for the education and then goal, principle, competition examinations, the status of appointment and assignments of the supervisors, regional service, reassignments, status of the spouse, health status, education disability and mission in regulations for Chairmanships of primary education supervisors along with the Chairmanships of education supervisors have been explained.

Legal Foundations for the Educational Supervision: T.R. Constitution- Article 42: Nobody can be left without the right of education and learning. The concept of the educational right is determined and regulated by law. Education and teaching, in the light of the Ataturk principles and revolutions, according to era science and education, has been done under the supervision and regulation of the State. Unified Teaching Law- Article 1: All science departments and education is connected to Ministry of Education in Turkey. Number 1702 law concerning the elementary and middle school teachers' promotion and punishment (Article 4): First time duty starts as an intern. At the end of the internship license and teaching capacity determined by training records and supervision report takes the title as a teacher. Number 1739 article of the National Education Basic Law (Article 17): The goals of the National Education are tried to be realized not only in the official and private education boards, at the same time at home, at the environment, at work, everywhere and at every opportunity. All the endeavors of the official, private and volunteer body regarding the education is subject to the supervision by the Ministry of National Education. Article 56: The Ministry of National Education is responsible for implementing, observing and supervision of the education and teaching services on behalf of the State under the articles of this law. Article 58 (Different: 16/6/1983-2842/16 Articles): Primary education school, high school and their equivalents in Turkey cannot be opened without the permission from the Ministry of National Education. The degree assignments of Schools opened or will be opened (including the military high schools) and private schools by the Ministry of National Education and from other ministries.

Number 3308 Vocational Education Law (Article 41): According to the terms of this law, the vocational education for apprentice candidate, apprentice and in official and private board and associations are supervised by the Ministry and the Ministry of Labor and Social Security Administration. Number 5580 Private School Boards Law (Article 10): The work permit of administrator, teacher, expert teacher and expert students who fail twice by the report of the supervision report will be canceled by issuing authority. Article 11: The boards and personnel working at these boards are under the supervision of watch of the Ministry. In the supervisions regarding the education-teaching and administration, the 
special law of the board is taken into consideration. Number 652 decree laws: With this law, the Chairmanship of Guidance and Supervision was established and an approach of preventing corruption in supervision, educating and guidance were focused. At the same time this decree law number 3797 Ministry of National Education Agency and Duties Law was cancelled.

Regulation for the Chairmanships of Primary Education Supervisors: It was published in 13.08.1999 went to sub-changes in 200, 2006 and 2009. The regulation dated 24.06.2011 66th article was cancelled. The Ministry of National Education in a regulation published in 1993, 2001, 2005, 2007 and 2012 went to changes. The purpose of the regulation of 1999, changed in 2005 and said "the goal of the regulation to organize the foundation concerning the primary school detectives and assistant detectives appointments and the qualities required for the appointees, duty, authority, responsibility, work tendency, preparation shape, change of place, guidance, research, evaluate, investigate, supervision and evaluation services". The "board" definition of 4th article in the 1999 decree was removed from the 2005 article. Articles 27, 28, 29, 32 and 33 "board" was changed with" the management of primary education school supervisors", articles 7, 9, 12, 13, 19, 20, 21 and 23 "personnel general directorate" was changed with "primary education directorate" articles 39 and 41 were changed with "pre evaluation". Main principles of the 1999, changed in 2005 main purposes were: “a) guidance, research, evaluation, questioning, and evaluating services and company activities and investigation information formation, duty dependent, job satisfaction and high moral providingi, b) to perform the personnel and body performances evaluation independently trustworthy, valid and openness principles". In 1999 in the last article of the required qualifications for those who would apply to the assistant supervisor position, changed in 2005 numbered 657 State Worker Law, 48th article A/5 sub-article carry out the requirements and in the last six months cut of salary or heavier disciplinary punishment required. In 2009 this last article was removed.

In 1999 regulation regarding the competition examination commission went to a change in 2005 and changed again in 2009 said "with the management of the deputy minister of appointed deputy minister assistant; supervisory board head or appointed assistant, primary education school general director or authorized general director assistant, personal general director or authorized assistant general director and appointed by the deputy minister one of the city primary education school supervisors Competition Examination commission is established". It can be seen that some of the units were removed from here. The rule of 1999 competition examination commission "written examination, to be done by the related department of the Ministry, to do the oral examination" article was removed from validity in 2006. The secretary services of the examination commission carried out by the elementary school General directorate." Article was changed as carried out by the Personnel General Directorate. Again in 2006, 70 written exam over 70 points would be called for an oral interview. In 2006 candidates with appointment sure to be appointed to which cities job was given to the General Directorate of primary education. In article concerning the duty area of the supervisors in 2005 pre-school education boards, elementary school boards, children with need for special education schools at the same level with the elementary school and classes, preparation and completing classes and courses, courses opened for the level of primary education school preparation courses, connected to private education boards, courses at elementary school level, course, etude education centers and schools, other schools/bodies which were seen appropriate by the governors and under the Ministry watch and control supervision and supervision work changed. In 2009, went for a change to make research added changed.

\section{Regulation for the Chairmanships of Educational Supervisors}

a. According to the regulation, to have the right to enter the examination was limited to 3 maximum. Examination subjects and weight changed, 30\% weight special interest knowledge was removed, Turkish-language knowledge 10\%, official correspondence rules 5\%, Ataturk's principles and revolutions $10 \%$, constitution $9 \%$, general culture $6 \%$, main rule $60 \%$ weight were given. The winners of supervisor assistant competition was given 10 choices whereas were being appointed by withdraw before. Before the assistant supervisor weren't appointed to the cities where they were born, or the last place they have work, this rule was changed. To those starting duty by winning the competition exam were given appropriate three stage training.

b. Changes regarding the appointments: Educational supervisors can stay maximum 8 years in a city where they work. Before in 1th and 2nd regions 1 supervisor for 90 teachers, in 3rd region 1 supervisor for 80 teachers, in 4 th region 1 supervisor for 70 teachers, now without making 
difference to the region 1 supervisor for 250 personnel. Spouse and health situation appointment permission was given.

c. On the subject regarding the learning disability change of place and for the condition that the supervisors to prove that they had postgraduate education, to the city where they had the post graduate education, to do duty and the need of investigator for the city want to be appointed additional regulations were done .

d. The duty scope of the assistant chairman was thought to be appropriate.

Research Objective: The objective of this research is to compare to regulations according to the opinions of the supervisors regarding many dimensions and evaluate. The answers to following question were sought: What were the opinions and recommendations of the supervisors about the appointment, preparation and reappointment dimensions of the regulation?

\section{Methodology}

Collecting of Data: The research is defining descriptive type research. In order to determine the views of the supervisors, a survey in three parts was used developed by the researchers depending on the regulations. In the first part of the survey personal information (6 each), in the second part changed in many dimensions (competition exam, conditions to apply to the exam, exam subjects and point weight, success criteria, to be appointed of investigator assistant, preparation, assignments, region service Pere quest, to determine the need of the region, change of place (health and spouse situation, learning disability) the points the supervisors obey, the enlarge their duty scope, managerial work and progress, temporary assignment) related 34 articles and in third section the supervisors with new regulations views and suggestions determination purpose open end one question. The trustworthiness ration is Cronbach Alpha $(\alpha)=0.877$.

Study Group: The study group of this research is consisted of chosen cities appointed supervisors in National Education Directorate $(n=74)$.

Evaluation of Data: The data obtained through survey in this research and SPSS 15.0 statistical program analyses. In the research sub-problems analysis, the average of the data was used. In explaining the obtained data Table 1 point gap was taken as a base.

Table 1: Score Intervals related to Options

\begin{tabular}{lll}
\hline Options & Grade & Score Interval \\
\hline Disagree & 1 & $1.00-1.79$ \\
Partly Agree & 2 & $1.80-2.59$ \\
Agree & 3 & $2.60-3.39$ \\
Strongly Agree & 4 & $3.40-4.19$ \\
Fully Agree & 5 & $4.20-5.00$ \\
\hline
\end{tabular}

\section{Results}

Findings regarding the supervisors' personal aspects: The personal aspects of the supervisors were given at Table 2 below. When Table 2 evaluated, $82.4 \%$ of the supervisors are male, $17.6 \%$ were female. $63.5 \%$ of the supervisors class teacher, $10.8 \%$ Turkish teachers' class. $39.2 \%$ of the supervisors 4 year Educational Administration and Supervision Department, 18.9\% 3+1 License completion and 17.6\% 2+2 license completion graduate. Of the supervisors 33.8\% 16-20 years, 24.3\% 11-15 years, 23\% 1-5 years, $10.8 \% 21-25$ years of seniority. 
Table 2: Personal Information of Supervisors

\begin{tabular}{|c|c|c|c|}
\hline \multicolumn{2}{|c|}{ Personal Information } & \multicolumn{2}{|c|}{ Supervisors } \\
\hline \multirow{3}{*}{ Gender } & Female & 13 & 17,57 \\
\hline & Male & 61 & 82,43 \\
\hline & Total & 74 & 100,00 \\
\hline \multirow{3}{*}{ Branch } & Class Teacher & 47 & 63,51 \\
\hline & Culture Subject Teacher & 27 & 36,49 \\
\hline & Total & 74 & 100,00 \\
\hline \multirow{6}{*}{ Seniority } & $1-5$ years & 17 & 22,97 \\
\hline & 6-10 years & 5 & 6,76 \\
\hline & $11-15$ years & 18 & 24,32 \\
\hline & $16-20$ years & 25 & 33,78 \\
\hline & $21-25$ years & 9 & 12,16 \\
\hline & Total & 74 & 100,00 \\
\hline \multirow{6}{*}{ Education } & In-service training course opened by M.E.B. & 1 & 1,35 \\
\hline & $\begin{array}{l}\text { Completion of } 2+2 \text { educational } \\
\text { administration and supervision license }\end{array}$ & 13 & 17,57 \\
\hline & $\begin{array}{l}\text { Completion of } 3+1 \text { educational } \\
\text { administration and supervision license }\end{array}$ & 14 & 18,92 \\
\hline & $\begin{array}{l}4 \text { year educational administration and } \\
\text { supervision department }\end{array}$ & 29 & 39,19 \\
\hline & Postgraduate & 17 & 22,97 \\
\hline & Total & 74 & 100,00 \\
\hline \multirow{5}{*}{$\begin{array}{l}\text { Duration of } \\
\text { Service }\end{array}$} & 10-15 years & 5 & 6,76 \\
\hline & $16-20$ years & 7 & 9,46 \\
\hline & $21-25$ years & 20 & 27,03 \\
\hline & $26-30+$ years & 42 & 56,76 \\
\hline & Total & 74 & 100,00 \\
\hline
\end{tabular}

Findings regarding the Sub-Problem: The opinions of the supervisors regarding the changes occurred in the dimensions explained in the new regulations in Table 3.

Table 3: The Opinions of Supervisors

\begin{tabular}{|c|c|c|c|}
\hline Opinions & $\mathbf{n}$ & $\bar{X}$ & SS \\
\hline $\begin{array}{l}\text { 1. It's appropriate to add the Chair of Supervisory Board or his appointed vice } \\
\text { chair to the competition and adequacy examination commission. } \\
\text { 2. It's appropriate to remove General Director of Primary Education, Preschool }\end{array}$ & 74 & 1,77 & 1,35 \\
\hline $\begin{array}{l}\text { General Director, Private Teaching Board, Education Technologies General } \\
\text { Directors (Art. 5) }\end{array}$ & 74 & 2,91 & 1,72 \\
\hline $\begin{array}{l}\text { 3. Additions of In the new regulation concerning the competition examination } \\
\text { subjects and point weights (Art.8); Turkish Republic Constitution, general } \\
\text { principles, main right and duties, main organs of the State and number } 4982 \text {, } \\
3071,5542,4483,5018,657 \text { and } 3628 \text { laws addition }(15 \%) \text { and point weight } \\
\text { change, general culture (reduced to } 10 \% \text { from } 15 \% \text { ), teaching profession } \\
\text { knowledge (reduced to } 25 \% \text { from } 30 \% \text { ), national education rules (reduced to } \\
15 \% \text { from } 20 \% \text { ) and attitude and behavior points }(10 \%) \text { appropriate. }\end{array}$ & 74 & 3,50 & 0,74 \\
\hline $\begin{array}{l}\text { duration in official schools and boards as a teacher, remaining three years as an } \\
\text { administrator in Ministry central or urban duties" is appropriate. }\end{array}$ & 74 & 1,66 & 1,14 \\
\hline $\begin{array}{l}\text { 5. The removal of the conditions for application to the supervisor assistant } \\
\text { competition examination "Faculty of Education, Administration, Supervision, }\end{array}$ & & & \\
\hline $\begin{array}{l}\text { Planning and Economy or Educational Administration and Supervision } \\
\text { Department/main science branch graduate or post graduate or doctorate at }\end{array}$ & 74 & 1,81 & 1,09 \\
\hline $\begin{array}{l}\text { least three years teaching and/or administration duties performed at official } \\
\text { school and boards of the Ministry" is appropriate (Art. 6-3) }\end{array}$ & & & \\
\hline $\begin{array}{l}\text { 6. The removal of the conditions to apply to competition examination "to be } \\
\text { condemned for a punishment which is not related to the supervisory profession }\end{array}$ & & & \\
\hline activities which is not at the degree of state employee but still convicted the & 74 & 1,72 & 1,01 \\
\hline
\end{tabular}


legal and administrative investigation removed from oneself" is appropriate. 7. The change as in the written examination "in the case of 70 or higher point receiving candidates the teams that were announced less than twice the number, the candidates who were successful in the written examination to be called for and oral examination" is appropriate.

8. The expression of "every candidate will be recorded from the time the oral examination start and until it ends sound and vision recorded" is appropriate (Art. 9-6)

9. Removal of the conditions of in case of point equality in the competition examination "in the ISBN (International document book standardization number) norms poem, article, story and similar work" condition and addition of the condition to serve in board directorate and aboard service is appropriate. 10. The change of the article of "regarding the announcement of the results of the competition examination "in fifteen days following the written examination will be announced at the Ministry and Provincial National Education Directorates" which was in the old regulation, to the "results of the examination, in twenty days following the oral examination will be put on the internet website by the Personnel General Directorate" is appropriate.

11. The change on the subject of appointment to the assistant inspector position "the appointments of the winners of the competition examination (Art 16) will be made according to their point superiority by their preferences taken into consideration" is appropriate.

12. The change of "in-service education and on the job training" with two stages in regards to the preparation program of supervisor assistant, "preparatory education, on the job training and theoretical training" three stages are appropriate.

13. The removal of the article "supervisor assistants cannot be appointed to the cities where themselves or their spouses registered in the registrar and to the cities where they last worked" is appropriate.

14. It's appropriate to remove the explanation "they will be appointed to the cities in need as supervisors" of appointments of supervisor assistants who became successful in adequacy examination and appropriate" to the cities where they have registered"

15. Increase of regional service from four years to five years in the third service regions.

16. In the subject of determining the need for supervisors of the cities, it's appropriate to change form "in first and second service regions 90, in third service regions 80 , in fourth and fifth service regions 70 teachers one supervisor will be appointed", to "the supervisor needs of the cities, for 250 personnel one supervisor every year appointment and change will be determined by the regarding board".

17. Regarding the periods which won't count as the regional service, it's appropriate to change "the military service won't count as the regional service" article "the military service after the main military training at the Ministry as a teacher completed included, the duration worked as a state employee will be considered in the service point calculation".

18. It's appropriate of addition the article "the service duration of the supervisors without a break more than eight years in the same city".

19. The changes made in the subject regarding for those with more than eight years' service in the same city is appropriate.

20 . The changes made in the subject of reappointments dependent of own request is appropriate.

21 . The changes in the subject reappointments of those completing the service duration in the region where they were appointed.

22 . The changes in the subject of reappointments depending of the spouse state disability.

23. The additions made regarding "the supervisors with children who need special education" regarding the changes on the subject of reappointments depending the health state disability is appropriate.

24. In the subject of reassignments dependent of the learning disabilities, the additional changes such as "supervisor and supervisor assistants with the condition that they can document they had completed post graduate education, they can be appointed to the city where they had post graduate education provide that there is a need for inspector in the city where they want to be appointed" is appropriate.

25. Regarding the subjects whom the supervisors and assistant supervisors will 
obey it's appropriate to remove the article "they cannot have personal contact and private relationship with the persons direct or indirectly related to audit investigation, evaluation and supervision. The subjects which were required by humanitarian and social relations were not included in these forbids".

26. The article "a supervisor cannot be appointed as the president for more than two times".

27. It's appropriate to remove the article "supervisors cannot be appointed as the president for the cities where themselves or their spouses are registered, born or at least more than five years lived".

28. Regarding the appointments of the Vice Chair, the addition is appropriate as "appointments of three vice presidents for the cities where the number of the supervisor and assistant supervisor are between 101 and 250, four in the cities between 251 and 300 , five in the cities more than 301" is appropriate.

29. It's appropriate to remove the article "supervisors cannot be appointed as the Vice Chair in the cities where they or their spouses were registered or at least lived more than five years".

30. It's appropriate to enlarge the area of duties of the Vice Chairs.

31. It's appropriate to continue the old regulation regarding the supervisor and assistant supervisor duty areas.

32. The changes regarding the subject of administrative work and concerning the supervisor and assistant supervisors.

33. The opinion of "the supervisors and assistant supervisors cannot be temporarily appointed at other institutions" is appropriate.

34. The new change as "the supervisors and assistant supervisors who completed their work period at the region where the city they work located, without the requirement of completing the inspector duties on $1^{\text {st }}$ September of the year when they completed two years of service, will be changed as to one of

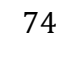

4,00

3,24

1,45

74 the cities they never worked before" is appropriate.

The views of the supervisors according to the data obtained in the Table 3 can be summed as follows:

a. Completion and examination commission addition of Supervisory Board Chair or appointed Vice Chair (Article 1: 1.77) and taking out the $6^{\text {th }}$ article which is the request for application for completion was never seen appropriate.

b. The condition for competition examination application required removal education administration of the universities, supervision, planning and economy graduate, post graduate and doctorate degree at least three years administration, teaching and/or administrator removal (Article 5: 1.81) and in the case of equal point score in the competition examination to have a scientific research, request of serving was added appropriate (Article 9: 2.07).

c. To call for verbal interviews to those who became successful on the written examination (Article 7: 3.28), assistant supervisors who are successful on the adequacy examination appointments to the cities where they have record of service, regional service to increase to five years in the third regions, the changes for those who serve in the same city for more than eight years, depending of demand, spouse dependent and disability dependent changes subject, the supervisors with children with special educational needs, for the matter that the supervisors and assistant supervisors need to obey "audit", investigate and research persons cannot interact in private business and conduct purchase" article (Article 25: 2.65) removal" supervisors themselves or spouses registered town, born or spouse registered or at least five years continuously lived city cannot be appointed as the president/vice president article (Article 27-29: 3.24-3.36) removal, enlargement of the duty of the president (Article 30: 2.86), supervisors' and assistant supervisors' job areas continue to be as the old regulation (Article 31: 2.85) and auditors managerial work and activities changes have seen "medium level" appropriate.

d. The supervisors, the competition examination subject and point weight regarding changes (Article 3: 3.50), for each candidate the time period from beginning to end, verbal and with vision recording (Article 8: 4.32), the appointments of the supervisors made to be dependent of the scores they receive (Article 11: 3.70), assistant supervisors placement in three instead of tow (preparing training, on the job training and theoretical training) (Article 12: 3.72), the need of supervisors of the cities one supervisor for 250 personnel (Article 16: 3.46), the regulation regarding the time which cannot be counted as the regional service (Article 17: 3.58), regarding 
the move depending on the health disability, the additional regulation for the supervisors with children with special educational needs (Article 23: 3.97), the article concerning the appointment of the supervisor twice for the same city (Article 26: 4.00), additional regulation regarding the assistant auditors (Article 28: 3.84), supervisor and assistant supervisors cannot be assigned temporarily to other departments (Article 33: 4.15) and for the assistant supervisors who complete the service period for the cities to a city they didn't serve before in the same region (Article 34: 3.70) found "appropriate".

\section{Conclusion}

When the supervisors opinions evaluated as generally, the supervisor expressed that they "didn't see appropriate" from the assistant supervisors competition examination Department of Educational Administration, Supervision, Planning and Economy to be graduate of, the removal of the special treatment for the post graduate and doctorate degree, accordingly "in the case of equal score points ISBN (International documents, books, standardization number) norm poem, article, story and etc. Condition removed" board directors and abroad service conditions to be added see not appropriate" shows that the disrespect for their work. Similarly, they see very appropriate that the verbal examinations to be recorded with voice and vision, in application examinations would be more objective, their opinion regarding the appointments to be made according to point superiority their sensitivity objective appointments. In the research open-ended question 35. "What should be the addition-removal and organization you would like to make in the Regulation of the Chairmanship of Educational Supervision" was answered only by three supervisors as to change the title of their job as "inspector" again. It has been thought that the reveal of the opinions of the other supervisors who are in the framework of the population of the research will be of great importance for the realization of the other legal arrangements as scientific and applicable.

\section{References}

Eğitim Müfettişleri $\quad$ Başkanlıkları Yönetmeliği

http://www.resmigazete.gov.tr/eskiler/2011/06/20110624-1.htm (in Turkish)

İlköğretim Müfettişleri Başkanlıkları Yönetmeliği (1999). http://mevzuat.meb.gov.tr/html/55.html (in Turkish)

Tevhidi Tedrisat Kanunu (1924). http://mevzuat.meb.gov.tr/html/110.html (in Turkish)

T.C. Anayasası (1982). http://mevzuat.basbakanlik.gov.tr/ (in Turkish)

625 sayılı Özel Öğretim Kurumları Kanunu (2007). http://mevzuat.meb.gov.tr/html/26434_0.html (in Turkish)

652 sayılı Kanun Hükmünde Kararname (2011). http://mevzuat.gov.tr (in Turkish)

1702 sayılı İlk ve Orta Tedrisat Muallimlerinin Terfi ve Tecziyeleri Hakkında Kanun (1930). http://mevzuat.meb.gov.tr/html/20.html (in Turkish)

1739 sayılı Milli Eğitim Temel Kanunu (1973). http://mevzuat.meb.gov.tr/html/88.html (in Turkish)

3308 sayılı Mesleki Eğitim Kanunu (1986). http://mevzuat.meb.gov.tr/html/3.html (in Turkish)

3797 sayılı Milli Eğitim Bakanlı̆̆ı Teşkilat ve Görevleri Hakkında Kanun (1992). http://mevzuat.meb.gov.tr/html/73.html (in Turkish)

5580 sayılı Milli Eğitim Bakanlığı Özel Öğretim Kurumları Kanunu (2007). http://mevzuat.meb.gov.tr/html/26434_0.html (in Turkish) 